\title{
EDUCATION AS A DEFINING CONDITION FOR COEVOLUTION
}

\section{Vasylieva O. M., Fugelo P. M.}

\section{INTRODUCTION}

Thoughtless intrusion of human into nature leads to rather bad consequences for it. Today, the changes introduced by human into the structure of the biota are global in scale and worsen the stability of the biosphere. It may happen that a small change in the load on the biosphere will be the beginning of its transition to a new quasi-stationary state, the parameters of which will exclude the possibility of intelligent life itself, at least in the modern sense of this word. The humanity simply will not be able to survive on the Earth without creating a society that is able to organize the sustainability of its development. According to scientists, the key role in this process should belong to science and education. The role of education in realization of the idea of sustainability is elucidated in a number of $\mathrm{UNESCO}^{1}$ and $\mathrm{UN}^{2}$ documents. The National System for CSD (Center for Sustainable Development) was developed by Ukraine $^{3}$. The issues concerning the process of transition to sustainable development and modernization of education in accordance with the foundations of sustainable development were considered in the works of domestic scientists: B. Danylyshin, V. Kutsenko, V. Pandik, S. Semenets, T. Yakheev and others.

The ideas of sustainable development, the role of education for the benefit of sustainability, the content of the concept of education,

${ }^{1}$ Education for Sustainable Development Goals: Learning Objective / UNESKO Education Sector. 2017. 67 p. URL: https://www.unesco.de/sites/default/files/201808/unesco_education_for_sustainable_development_goals.pdf.

2 Организация Объединенных наций / Экономический и Социальный Совет. Европейская экономическая комиссия. Стратегия ЕЭК ООН для образования в интересах устойчивого развития. Материалы Совещания высокого уровня представителей министерств окружающей среды и образования (Вильнюс, 17-18 марта 2005 года). Вильнюс, 2005. URL: https://unece.org/DAM/env/ documents/2005/cep/ac.13/cep.ac.13.2005.3.rev.1.r.pdf.

3 Цілі сталого розвитку: Україна : національна доповідь / Міністерство економічного розвитку i торгівлі України, 2017. 176 с. URL: http://un.org.ua/images/SDGs_NationalReportUA_Web_1.pdf. 
pedagogical practices, terminology in the field of sustainable development, institutions in the field of education, the socio-cultural content of education in the area of sustainable development can be found in the works of the following scientists: A.E. Vysotskaya ${ }^{4}$, A.N. Khmelevskaya ${ }^{5}$, J.D. Sachs ${ }^{6}$, L.-A. Wolff, P. Sjoblom, M. HofmanBergholm, I. Palmberg ${ }^{7}$ and others.

The analysis of the works on education in the field of sustainable development gives grounds to separate and highlight the issues that, in the opinion of the authors, are very relevant, but are not sufficiently covered. Among them the following are: educational problems in less developed countries; threats and their causes in various spheres of human activity; methods of influence on the ethics system of an individual; the quality of education.

The objective of the research is separation of the problematic issues related to education in the field of sustainable development and the presentation of their own vision of their solution, as well as the analysis of concepts that are considered as the scientific basis for coevolution.

According to the formulated objectives, the following research tasks are defined:

1) justification of the urgency of the problem of sustainable development;

2) explanation of the role of safety as a foundation for sustainability;

3) separation of educational problems in the sustainable development;

4) elucidation of the importance of the ethics in the problem of the coherence between the nature and a human and justification of the need in activation of formation of an moral system in youth.

The methodological basis of the research is formed by psychological principles and provisions on a systems concept of understanding of a personality, an activity-based approach to the formation and readiness of

4 Висоцька О.С. Освіта для сталого розвитку : науково-методичний посібник. Дніпропетровськ : Роял Принт, 2011. 200 с.

5 Хмелевська О.М. Освіта для сталого розвитку: зміст та інституції. Демографія та соиіальна економіка. 2018. № 1 (32). С. 29-42.

6 Jeffrey D. Sachs. The Age of Sustainable Development. New York, US : Columbia University Press, 2015. 543 p. URL: file://C:/Users/User/Downloads/Sachs.\%20\%20Food\%20Security.pdf.

${ }^{7}$ Wolff L-A, Sjöblom P., Hofman-Bergholm M., Palmberg I. High Performance Education Fails in Sustainability? - A Reflection on Finnish Primary Teacher Education. Education Sciences. 2017. № 7 (1). P. 32. URL: https://doi.org/10.3390/educsci7010032. 
a person to live in harmony with the environment, as well as the methods of abstraction, transition from the abstract to the specific one, analysis and synthesis, and synergetic methodology.

\section{Eco-development is a vital problem of the present}

After a number of scientific achievements and discoveries of the XVII XIX centuries, a human began to consider the nature as a storehouse of raw materials for its needs. Human has already subdued nature to such an extent that the latter has almost depleted its resources. Considering at the same time the fact that the needs of the humanity and scientific and technical resources are unlimited, the pressure on the nature has reached a critical point, what has resulted in an environmental crisis.

"Environmental problems are not the problems that have fallen down on our civilization, but it is a natural result of its development. They are the result of disharmony between the biosphere and the noosphere, the product of a limited vision of the nature, expressed in the use of imperfect technology that is sometimes destructive in terms of its aftereffects" 8 .

Human activities have always been directed against the biota. The destruction of the formed biocenoses began in prehistoric times, and now the changes already introduced by human into the structure of the biota have geological scales. The transformation into a desert of the vast and fertile territories of North Africa and the Middle East is not a consequence of any drastic changes in the climate, but it is a direct result of human activities. In recent decades, the harmful effects on biota have intensified. Moreover, with an increase in the level of development of the civilization, the pressure on the environment also increases. This situation resembles a paradox. But a civilization is interpreted as a synonym for culture, a set of material and moral achievements of a society ${ }^{9}$. Culture itself is the basis for the humanization of being ${ }^{10}$ and it is incompatible with the concepts: threat, danger, harm.

The ideas that the culture and the civilization are opposites were expressed at the beginning of the twentieth century. "Culture and

8 Кочеткова Т.Ю. Парадигма самоорганизации и современная экологическая ситуация. Практическая философия. 2003.№ 1. С. 105-113.

9 Украинский Советский Энциклопедический Словарь : в 3 т. / редкол.: А.В. Кудрицкий (отв. ред.) и др. Киев : Глав. Ред УСЭ, 1989. Т. 3.593 с.

10 Васильєва О.М., Фугело М.А., Фугело П.М. Формування культури як основа гуманізації буття. Освітній дискурс : збірник наукових праць. Вип. 23 (5). Київ : ТОВ «Науково-інформаційне агентство «Наука, технологія, інформація», 2020. С. 39-54. DOI: 10.33930/ed.2019.5007.23(5)-4. 
civilization is a living body of soulfulness and its mummy"11. This means that there may be a discrepancy between the concepts of a "cultured person" and a "civilized person". A cultured person is inseparable from the universal system of values, humanism and responsibility for the results of its creative activities. A civilized person keeps up with scientific and technical achievements, it is developed, acts freely and independently, adhering to the code of behavior defined in a society related with it, but at the same time it can violate the rights of other people, neglects possible threats to society, the consequences of its activities and has an insufficiently formed system of humanistic values.

A great threat to humanity is the ability of dulling of the responsibility for the actions done, what is typical for some civilized individuals. Manifestations of "civilized lack of culture" are quite common. Today they can be observed in the form of wars, conflicts, terror towards people and nature. The evidence of the described manifestations is also the situation when highly civilized countries, for the sake of their enrichment, take inhuman actions against backward states. Environmental collaborism causes great harm to the environment.

"Civilized lack of culture" is one of the reasons for the aggravation of the crisis regarding attitude of a human to the nature. Civilized, but uncultured persons loose today for the sake of enrichment the possibility of a safe life for people in the future. "Since the beginning of the industrial revolution, atmospheric $\mathrm{CO}_{2}$ reserves have increased by one third - such rates of growth have not been observed at least during the previous period of 20,000 years long. The today's level of concentration of greenhouse gases in the atmosphere exceeds the natural level, which has not been observed over the past 650,000 years long ${ }^{12}$.

According to the researchers V.N. Danilov-Danilyan and K.S. Losev ${ }^{13}$ almost half of all available fresh water is polluted annually in the world.

Every year, thousands of fires are recorded on our planet, caused by people. Fire destroys everything that comes in its way, especially grass and trees. By destroying vegetation, a person changes the albedo, i.e., the reflecting power of the earth surface, disrupting thereby the basis of the

11 Шпенглер О. Закат Европы. Очерки морфологии мировой истории. Москва : Мысль, 1993. 538 с.

12 Вебер А.Б. Глобальное изменение климата. Кто виноват? И что делать? Век глобализациии. 2008. № 1. С. 70-75.

13 Данилов-Данильян В.И., Лосев К.С. Потребление воды: экологический, экономический, социальный и политический аспекты. Москва : Наука, 2006. 221 c. URL: http://ecsocman.hse.ru/text/33440596. 
thermodynamic equilibrium of the atmosphere. A change in average temperatures leads to a change in the structure of atmospheric circulation and to a climate change.

One of the key global threats is a rapid growth of poor population and worsening of living conditions in the less developed countries. Problems with raw materials and energy are growing. Poverty in the less developed countries is associated with various types of risks, including many environmental ones. This can be illustrated by the example of transformation by developed states of less developed countries into their raw material appendages, what in its turn assists in the depletion and saturation of their lands with pesticides, destruction of forests and all the fauna associated with them. Location of hazardous industries of rich countries in the territories of impoverished countries also assists in poisoning of water, air and human health. But such method for minimization of the risks in developed countries is unreliable. According to the research by P.A. Vaganov there is a "boomerang effect"14 in risk society. There are no state borders for environmental disasters, because products grown in poor countries and saturated with various chemicals end up on the tables of the population of rich countries, just like sea-water or ocean fish poisoned by the waters of the rivers of backward countries.

The analysis of the research and studies mentioned above shows that the global problem of the present is to define the conditions for the coherence between a human and the biosphere. People must learn to appreciate nature and take responsibility for the fate of the biota, because, as V. Vinnichenko said, this is their fate, too.

The philosophical views of this thinker are permeated with love and respect for nature. He saw human happiness in the balance of all human values and their consistency between themselves and the outside world. People's neglect of harmony with nature leads to disasters. The scientist hoped that the time will come when people will understand this and embark upon the path of development consistent with the environment. "And then the Earth will become the planetary garden of paradise, and this is not in an allegory, but in the reality"15.

14 Ваганов П.А., Манг-Сунг Им. Экологические риски. Санкт-Петербург : изд-во Санкт-Петербургского университета, 2001. 152 с.

15 Винниченко В.К. Конкордизм. Система будування щастя: етикофілософський трактат / передмов. Т.I. Гундорової. Київ : Український письменник, 2011. С. 256. 
Though very slowly but V. Vinnichenko's plans on the ecodevelopment of the society are beginning to come true and be implemented. The UN Conference on Environment and Development (Rio de Janeiro, 1992) adopted the concept of sustainable development. It is based on the idea of consistency in the management of the economic, social and environmental spheres. This concept is recognized by the world community as a strategy for the existence of the Earth for the 21 st century ${ }^{16}$.

\section{Safety as the foundation of sustainability}

One of the conditions for life, self-preservation and progress of a society is the absence of threats.

Safety is a state when nothing threatens someone or something, does not cause concern ${ }^{17}$.

Safety is associated with the conditions under which the rights and the civil liberties of every person and the sustainability of the country development are guaranteed. The problem of protection from dangers and their prevention has always been and remains the most important problem. The analysis of the dangers and risks of the present shows that the cause of the overwhelming majority of them is the human factor.

Today, the harmful consequences and effects caused by human influence on the environment are so large on a global scale that they have led to an ecological crisis. Its signs are reflected in changes that pose a threat to human life and the environment. The problem of minimization of the risks for human development dictates the need in joining together international efforts in order to develop joint safety measures. So, ensuring safety is an integral part of a series of sequential actions aimed at defining tactics and strategies for ensuring the progress of the society.

Ensuring of the sustainable development of the society is a problem that is dependent on many factors (political, economic, social, and scientific), each of them is characterized by its proper threats (see table 1).

\footnotetext{
16 Програма XXI : Конференція ООН 3 навколишнього середовища та розвитку, червень 1992 року. Ріо-де Жанейро, 1992. URL: https://www.un.org/ru/documents/decl_conv/declarations/riodecl.shtml.

17 Сучасний тлумачний словник української мови: 60000 слів / за заг. ред. В.В. Дубічинського. Харків : ВД «ШКОЛА», 2009. С. 52.
} 


\section{Areas of research in the field of safety ${ }^{18}$}

\begin{tabular}{|c|c|c|c|c|}
\hline № & $\begin{array}{c}\text { Fields of } \\
\text { safety (area } \\
\text { of research) }\end{array}$ & Safety objects & $\begin{array}{l}\text { The main } \\
\text { causes of risks } \\
\text { and threats }\end{array}$ & $\begin{array}{l}\text { The most } \\
\text { significant risks } \\
\text { and threats }\end{array}$ \\
\hline 1 & Geopolitical & $\begin{array}{l}\text { International } \\
\text { corporations, } \\
\text { states }\end{array}$ & $\begin{array}{c}\text { Excessive } \\
\text { profits, } \\
\text { imperfect laws, } \\
\text { territorial } \\
\text { claims }\end{array}$ & $\begin{array}{l}\text { Military conflicts, } \\
\text { mafia showdowns, } \\
\text { grand thefts, } \\
\text { international } \\
\text { terrorism, wars, } \\
\text { drug business }\end{array}$ \\
\hline 2 & Political & $\begin{array}{c}\text { Parties, social } \\
\text { movements, } \\
\text { power structures }\end{array}$ & $\begin{array}{l}\text { Crisis of power, } \\
\text { imperfect laws }\end{array}$ & $\begin{array}{l}\text { Corruption, growth } \\
\text { of organized crime, } \\
\text { terrorism, } \\
\text { criminalization of } \\
\text { the society, } \\
\text { economic relations, } \\
\text { contract killings }\end{array}$ \\
\hline 3 & Economic & $\begin{array}{l}\text { Production and } \\
\text { commercial } \\
\text { spheres }\end{array}$ & $\begin{array}{c}\text { Excessive } \\
\text { profits, } \\
\text { imperfect laws, } \\
\text { tax policy }\end{array}$ & $\begin{array}{l}\text { Mafia showdowns, } \\
\text { laundering of dirty } \\
\text { money, destruction } \\
\text { of enterprises, } \\
\text { production, trade, } \\
\text { barbaric use of } \\
\text { natural resources, } \\
\text { pollution of the } \\
\text { environment }\end{array}$ \\
\hline 4 & Social & $\begin{array}{l}\text { Social groups, } \\
\text { public } \\
\text { organizations }\end{array}$ & $\begin{array}{l}\text { Irregularity in } \\
\text { distribution of } \\
\text { material wealth, } \\
\text { poverty, } \\
\text { inequality of } \\
\text { rights } \\
\end{array}$ & $\begin{array}{c}\text { Criminalization of } \\
\text { society, social } \\
\text { groups, } \\
\text { relationships, } \\
\text { people, social } \\
\text { conflicts, terrorism }\end{array}$ \\
\hline 5 & Demographic & $\begin{array}{l}\text { People, groups of } \\
\text { people }\end{array}$ & $\begin{array}{l}\text { Overpopulation, } \\
\text { decline of } \\
\text { medicine, } \\
\text { chang in } \\
\text { regional-ethnic } \\
\text { proportions and } \\
\text { distribution of } \\
\text { benefits }\end{array}$ & $\begin{array}{l}\text { Genocide, ethnic } \\
\text { armed conflicts, } \\
\text { reduced life } \\
\text { expectancy, } \\
\text { extinction of the } \\
\text { population, nations }\end{array}$ \\
\hline 6 & Food & Foodstuffs & $\begin{array}{c}\text { Insufficiency of } \\
\text { food, depletion } \\
\text { of agricultural } \\
\text { lands }\end{array}$ & $\begin{array}{l}\text { Production of poor- } \\
\text { quality foodstuffs, } \\
\text { mass poisoning of } \\
\text { the population }\end{array}$ \\
\hline
\end{tabular}

18 Ярочкин В.И. Секьюритология - наука о безопасности жизнедеятельности. Москва : Ось-89, 2000. 400 с. 


\begin{tabular}{|c|c|c|c|c|}
\hline 7 & Culturological & $\begin{array}{l}\text { Ethics, } \\
\text { spirituality }\end{array}$ & $\begin{array}{l}\text { Decrease in the } \\
\text { spiritual and } \\
\text { moral level and } \\
\text { morality }\end{array}$ & $\begin{array}{c}\text { Moral } \\
\text { licentiousness, } \\
\text { licentiousness, } \\
\text { growth of } \\
\text { alcoholism, drug } \\
\text { addiction, } \\
\text { prostitution, crime } \\
\text { figures }\end{array}$ \\
\hline 8 & $\begin{array}{l}\text { Energetic and } \\
\text { informational }\end{array}$ & $\begin{array}{l}\text { Consciousness, } \\
\text { subconsciousness } \\
\text { of a person }\end{array}$ & $\begin{array}{c}\text { Unauthorized } \\
\text { energetic and } \\
\text { informational } \\
\text { impact }\end{array}$ & $\begin{array}{l}\text { Unconscious } \\
\text { criminal actions, } \\
\text { zombieing }\end{array}$ \\
\hline 9 & Military & $\begin{array}{l}\text { Armament and } \\
\text { military } \\
\text { equipment }\end{array}$ & $\begin{array}{l}\text { Insufficient } \\
\text { protection of } \\
\text { weapons and } \\
\text { military } \\
\text { equipment }\end{array}$ & $\begin{array}{l}\text { Theft of weapons } \\
\text { and military } \\
\text { equipment, } \\
\text { explosives, blowing } \\
\text { up of warehouses, } \\
\text { pollution of the } \\
\text { environment with } \\
\text { radiation and } \\
\text { poisonous } \\
\text { substances, } \\
\text { terrorism } \\
\end{array}$ \\
\hline 10 & Informational & $\begin{array}{l}\text { Information and } \\
\text { its infrastructure }\end{array}$ & $\begin{array}{l}\text { Imperfect } \\
\text { informational } \\
\text { infrastructure } \\
\text { and the laws }\end{array}$ & $\begin{array}{l}\text { Theft, destruction, } \\
\text { distortion, } \\
\text { disclosure of } \\
\text { information, } \\
\text { economic } \\
\text { espionage, } \\
\text { blackmail }\end{array}$ \\
\hline 11 & $\begin{array}{l}\text { Scientific and } \\
\text { technical }\end{array}$ & $\begin{array}{l}\text { Know How, } \\
\text { leading-edge } \\
\text { technologies }\end{array}$ & $\begin{array}{l}\text { The possibility } \\
\text { of use of } \\
\text { KNOW-HOW } \\
\text { and leading- } \\
\text { edge } \\
\text { technologies for } \\
\text { criminal } \\
\text { purposes }\end{array}$ & $\begin{array}{l}\text { Use of KNOW- } \\
\text { HOW and leading- } \\
\text { edge technologies } \\
\text { for criminal } \\
\text { purposes x }\end{array}$ \\
\hline 12 & Ecologic & Environment & $\begin{array}{c}\text { Environmental } \\
\text { degradation }\end{array}$ & $\begin{array}{c}\text { Production of } \\
\text { ecologically "dirty" } \\
\text { foodstuffs and other } \\
\text { products, } \\
\text { criminogenic use of } \\
\text { "clean" territories, } \\
\text { an increase in the } \\
\text { number of refugees } \\
\text { and miserable } \\
\text { persons }\end{array}$ \\
\hline
\end{tabular}


In addition to the fields of safety represented in the table, we should also add "educational one". The main causes of the risks and threats in this field lie in the low level of knowledge and it's lagging behind the needs of today, as well as in the enticement of intellectual potential from underdeveloped countries. The most significant risks and threats posed by these factors are manifested in unjustified economic decisions, production errors and miscalculations, what is equivalent to losses and damage of various natures and this also deprives countries with a low level of development of vanguard force, what leads to their overall degradation.

The existence of human and the environment is constantly associated with risks and dangers (environmental, military, socio-economic, technogenic ones). The effectiveness of avoiding and prevention of these threats depends on the degree of study of these causes at all hierarchical levels (table 2).

Table 2

Areas of research at hierarchical levels ${ }^{19}$

\begin{tabular}{|c|c|c|c|c|}
\hline № & $\begin{array}{l}\text { Hierarchical } \\
\text { levels of the } \\
\text { areas of } \\
\text { research }\end{array}$ & $\begin{array}{l}\text { Safety } \\
\text { objects }\end{array}$ & $\begin{array}{l}\text { The main causes of } \\
\text { risks and threats }\end{array}$ & $\begin{array}{l}\text { The most significant } \\
\text { risks and threats }\end{array}$ \\
\hline 1 & $\begin{array}{l}\text { Noosphere } \\
\text { safety }\end{array}$ & Noosphere & $\begin{array}{l}\text { Aggravation of global } \\
\text { problems: demographic, } \\
\text { energetic, environmental }\end{array}$ & $\begin{array}{l}\text { The emergence of world } \\
\text { wars, including nuclear } \\
\text { war, the ability to } \\
\text { destroy the noosphere }\end{array}$ \\
\hline 2 & $\begin{array}{l}\text { Safety of } \\
\text { regions }\end{array}$ & $\begin{array}{l}\text { Union of } \\
\text { states }\end{array}$ & $\begin{array}{c}\text { Aggravation of } \\
\text { international relations, } \\
\text { environmental situation }\end{array}$ & $\begin{array}{l}\text { The emergence of } \\
\text { regional conflicts and } \\
\text { wars }\end{array}$ \\
\hline 3 & State safety & State & $\begin{array}{l}\text { Deterioration of the } \\
\text { situation in the } \\
\text { economic, social, } \\
\text { political and other } \\
\text { spheres of safety }\end{array}$ & $\begin{array}{c}\text { Civil wars, breakup of } \\
\text { the state }\end{array}$ \\
\hline 4 & $\begin{array}{l}\text { Safety of the } \\
\text { society }\end{array}$ & $\begin{array}{l}\text { Society, } \\
\text { social } \\
\text { group }\end{array}$ & $\begin{array}{l}\text { Irregularity in } \\
\text { distribution of material } \\
\text { wealth, impoverishment, } \\
\text { violation of the rights of } \\
\text { the population }\end{array}$ & $\begin{array}{l}\text { Criminalization of } \\
\text { society, the emergence } \\
\text { of social conflicts, } \\
\text { including armed } \\
\text { conflicts }\end{array}$ \\
\hline 5 & $\begin{array}{l}\text { Safety of an } \\
\text { individual }\end{array}$ & Human & $\begin{array}{l}\text { Poverty, violation of the } \\
\text { rights, lack of protection, } \\
\text { lack of freedom, } \\
\text { starvation, diseases }\end{array}$ & $\begin{array}{l}\text { Murder, kidnapping, } \\
\text { torture, robbery, theft, } \\
\text { threats, blackmail, } \\
\text { intimidation }\end{array}$ \\
\hline
\end{tabular}

19 Ярочкин В.И. Секьюритология - наука о безопасности жизнедеятельности. Москва : Ось-89, 2000. 400 с. 
Studying the problem of safety, we cannot ignore the issue of its assessment. The quantitative measure for safety is the risk. The Economic Encyclopedia ${ }^{20}$ gives the definition: "risk" is an attribute of decision-making in a situation of uncertainty.

In practice, depending on the content of the task, the following indicators are used to assess the risk:

1) the probability $(\mathrm{P})$ of the occurrence of an event that results in losses;

2) the width (W) of undesirable effects and consequences for the given event.

The perception of risk by each person is individual and it depends on the following factors: psychological, social, cultural, geographical factor etc.

Unfortunately, most people cannot assess the risks, which often leads to harm, and not only to the people themselves. The psychological perception of the risk by society seems to contradict the moderation (table 3).

Table 3

The results on ranking of the risk levels ${ }^{21}$

\begin{tabular}{|c|c|c|c|c|c|}
\hline \multirow{2}{*}{$\begin{array}{c}\text { Technologies } \\
\text { and branch of } \\
\text { activities }\end{array}$} & businessmen & students & $\begin{array}{c}\text { members } \\
\text { of a } \\
\text { women's } \\
\text { club }\end{array}$ & experts & $\begin{array}{c}\text { Geometric mean for groups } \\
\text { annual } \\
\text { mortality }\end{array}$ \\
\hline Nuclear power & 1 & 1 & 8 & 20 & 100 \\
\hline $\begin{array}{c}\text { Ground } \\
\text { transport }\end{array}$ & 2 & 5 & 3 & 1 & 50000 \\
\hline Fire arms & 3 & 2 & 1 & 4 & 17000 \\
\hline Smoking & 4 & 3 & 4 & 2 & 150000 \\
\hline $\begin{array}{c}\text { Motorcycle } \\
\text { driving }\end{array}$ & 5 & 6 & 2 & 6 & 3000 \\
\hline $\begin{array}{c}\text { Alcohol } \\
\text { consumption }\end{array}$ & 6 & 7 & 5 & 3 & 100000 \\
\hline Private aviation & 7 & 15 & 11 & 12 & 1300 \\
\hline Work in police & 8 & 8 & 7 & 17 & 160 \\
\hline Pesticides & 9 & 4 & 15 & 8 & \\
\hline Surgery & 10 & 11 & 9 & 5 & 2800 \\
\hline Fire-fighter job & 11 & 10 & 6 & 18 & 195 \\
\hline \multicolumn{5}{|c|}{}
\end{tabular}

${ }^{20}$ Економічна енциклопедія : у 3 т. Т. 3 / відп. ред С.В. Мочерний та ін. Київ : вид. центр «Академія», 2002. 952 с.

21 Ваганов П.А., Манг-Сунг Им. Экологические риски. Санкт-Петербург : изд-во Санкт-Петербургского университета, 2001. 152 с. 


\begin{tabular}{|c|c|c|c|c|c|}
\hline $\begin{array}{c}\text { Large } \\
\text { structures }\end{array}$ & 12 & 14 & 13 & 13 & 1100 \\
\hline Hunting & 13 & 18 & 10 & 23 & 800 \\
\hline $\begin{array}{c}\text { Aerosol spray } \\
\text { cans }\end{array}$ & 14 & 13 & 23 & 26 & \\
\hline Alpinism & 15 & 22 & 12 & 29 & 30 \\
\hline Bicycling & 16 & 24 & 14 & 15 & 1000 \\
\hline $\begin{array}{c}\text { Commercial } \\
\text { aviation }\end{array}$ & 17 & 16 & 18 & 16 & 130 \\
\hline Electric energy & 18 & 19 & 19 & 9 & 14000 \\
\hline $\begin{array}{l}\text { Swimming in } \\
\text { ponds }\end{array}$ & 19 & 30 & 17 & 10 & 3000 \\
\hline $\begin{array}{c}\text { Contraceptive } \\
\text { agents }\end{array}$ & 20 & 9 & 22 & 11 & 150 \\
\hline $\begin{array}{l}\text { Mountain } \\
\text { skiing }\end{array}$ & 21 & 25 & 16 & 30 & 18 \\
\hline $\begin{array}{c}\text { X-ray } \\
\text { (medicine) }\end{array}$ & 22 & 17 & 24 & 7 & 2300 \\
\hline $\begin{array}{l}\text { Football } \\
\text { (injuries) }\end{array}$ & 23 & 26 & 21 & 27 & 23 \\
\hline Railway & 24 & 23 & 20 & 19 & 1950 \\
\hline $\begin{array}{c}\text { Food } \\
\text { preservatives }\end{array}$ & 25 & 12 & 28 & 14 & \\
\hline Food colors & 26 & 20 & 30 & 21 & \\
\hline Motocars & 27 & 28 & 28 & 28 & 24 \\
\hline Antibiotics & 28 & 21 & 26 & 24 & \\
\hline $\begin{array}{l}\text { Household } \\
\text { appliances }\end{array}$ & 29 & 27 & 26 & 22 & 200 \\
\hline Vaccination & 30 & 29 & 27 & 25 & 10 \\
\hline
\end{tabular}

The table reflects the indicators of the persons interviewed in relation to some aspects of ethical principles, attitudes towards themselves and the environment, as well as towards the gaps in school education concerning the issues on formation of the integrity of the perception of the world.

The end of the 20th century is characterized by an increase of various dangers and risks that they cause. German scientist Ulrich Beck called the new phase of human development as the risk society. In the process of development of such a society, there appear more and more negative factors that are inherent in an uneven distribution between the members of the society. Thus, in an industrial society, positive achievements are mainly produced and distributed, and in a risk society that "grows" into an industrial society, the negative effects and consequences of the 
development of the latter are accumulated and distributed among the members ${ }^{22}$.

As research and studies by U. Beck ${ }^{20}, \mathrm{~N}$. Luhmann ${ }^{23}$, A. Rennes ${ }^{24}$ and other scientists showed, the basis for the theory of "risk society" is determined mainly by the risks caused by the technosphere. In such a situation, the opportunity to be prepared for the dangers is lost, the level of protection of society decreases, what explains the inconsistency between the type of threats and preventive safety measures.

A characteristic feature of a risk society is the dependence on the future, what requires the control of modern high technologies, an assessment of their risk level and, according to Beck, changes in the motivation of people's behavior. In a risk society, solidarity concerning needs must be replaced by solidarity concerning anxiety, what can become a significant political force ${ }^{14}$. In the education system, safety should become a part of the educational process and be considered as a condition for organization of the life in the 21 st century.

\section{Educational problems of sustainable development}

The UNECE (UN Economic Commission for Europe) Strategy in the field of education for benefit of sustainable development (March 2005) interprets the following: education should provide people and society with the ability to work for the sake of sustainable development. Its objective is to make people more informed, moral, responsible and demanding.

To achieve the effectiveness of education the following is necessary:

- to integrate it into academic disciplines, programs, courses or the organization of individual courses;

- to advance experience;

- teachers shall cooperate with other participants of the process;

- reveal the essence of environmental problems;

- to implement new approaches in the education.

The content of the education in the field of sustainable development should be based on the following principles:

- collective responsibility;

22 Бек У. От индустриального общества к обществу риска. THESIS. 1994. № 5. C. 161-168.

23 Луман Н. Понятие риска. THESIS. 1994. № 5. С. 135-160.

24 Ортвин Р. Три десятилетия исследования риска: достижения и новые горизонты. Вопросы анализа риска. 1999. Т. 1. № 1. С. 80-90. 
- respect for other people, their culture; tolerance and dialogue;

- creation of a humane society;

- acknowledgement of spirituality as an integral indicator of social development;

- educational institution as the main link in the provision with skills and knowledge;

- changes in the activities of educational institutions and the education management system based on the values of sustainable development;

- implementation of advanced technologies;

- development of the content, general criteria of effectiveness.

The most significant tasks of education in the field of sustainable development are the following:

- use of advanced technologies;

- implementation of the principles of the environmental ethics;

- all-round development of the spiritual capabilities of an individual;

- observance of the principles of multiculturalism and tolerance;

- development of the legal culture of an individual;

- formation of a socially active individual;

- inculcation of information culture in an individual;

- formation of a health culture in young people.

The main components of advanced education in the field of sustainable development are the following:

- ecological component;

- legal component;

- social and economic component;

- moral and ethical component.

Despite the fact that the majority of the population in the country sees value in education in the field of sustainable development, however, its development is proceeding, unfortunately, at a rather slow pace. This is explained by the lack of an ideal ideology for this type of education. Within its scope, in order to achieve the objective in view, the following shall be clearly defined: whom to teach; what to teach; in what forms? Education focused on sustainable development should train specialists who shall be able to solve not only technical, biological, but also necessarily complex social and economic problems. Only in this case the state will have a specialist that will be able to define the key part of the environmental problem, assess the risks and offer a practical solution.

Sustainable success in the educational sphere can be achieved only when the educational system is based on the national historical and cultural 
traditions. A state has a future only when its history continues on the basis of its own traditions. This undeniable truth has been proven by the history.

Since 1999, the education sector in most European countries has taken the form of the Bologna Process. Since 2005, Ukraine has joined this process. The Bologna Process is associated with reforms aimed at the creation of a general European Education Area. One of the objectives of reformation is to assist in mobility through overcoming the obstacles to ensure the movement of applicants for education, teachers, researchers, and administrative staff.

For economically strong countries, this is profitable, since the materially interested intellectual capital (the present and the prospective one) of the less developed countries will move exactly there. This is vividly demonstrated by the example of our state. Tens of thousands of applicants for higher education and teachers (doctors and candidates of science) study and work abroad. Due to the outflow of young hopefuls from Ukraine, many institutions of higher education in the state have problems with admission of students, and not only because of the shortage, but also because of the quality of their knowledge. It is because applicants with average level of knowledge remained on the territory of the Motherland, and young people with high intellectual training became applicants for education in foreign educational institutions. The absence of intellectual leaders in teaches groups who play the role of an example have effect on the success and progress of the whole group. So, the Bologna process, in accordance with some items of the Bologna Declaration, is disadvantageous for the less developed countries, since it assists in the drain of intellectual capital from them.

It should be also noted that the Bologna Process raises doubts concerning its effectiveness in terms of acquisition of knowledge. The European Credit Transfer System (ECTS) has been implemented in Europe since 1989. It is based on the assessment of all types of work of an applicant for education that are necessary to achieve the objective defined by the educational and training program. The model for organization of the educational process is a credit-modular system that combines modular technologies of education and educational units (credits). Reduction of the load on the student by canceling examinations is considered as its main advantage. There are different opinions on how such a system affects the quality of knowledge. Our research, carried out on the basis of the analysis of the scientific literature and surveys of teachers and lecturers of the institutions of higher education, shows that about $60 \%$ of teachers and lecturers acknowledge the acceptance of the 
credit-modular system for organization of the educational process due to its convenience and up-to-dateness. The low level of knowledge of the students is associated with a small stock of knowledge provided by the school. $40 \%$ of teachers think that the modular system does not assist in the thoughtful digestion of knowledge due to the lack of a holistic vision of the academic discipline. It turns into hunting for points. Students are more interested in rating than in knowledge and skill set. The results of the performed comprehensive works show a very low level of knowledge in the subjects where the test or exam was passed "automatically". Applicants for education preparing for the exams have more solid and stable knowledge after passing it. Therefore, the path to knowledge is still through overcoming difficulties.

Another problem associated with the modular credit system is the independent study of disciplines. Large scopes of tasks ensure that fact that a large number of applicants for education have very superficial knowledge on the disciplines that they studied independently. It is impossible to develop education only on the basis of a foreign experience, because the foreign methods do not take into account the national characteristics, traditions, social and economic processes of each individual country. Therefore, the low effectiveness of the credit-modular system in some countries can be explained not by its disadvantages, but by the conditions in which it is applied. The transition to sustainable development is a global process that requires the simultaneous transition of all countries to this model. Since the level of economic development of the countries is different, there arise problems that are waiting for their solution, especially problems related to education. In particular, how to form ecological etiquette in youth in the countries where forests are cut down and sold for the sake of survival, animals included into the Red Data Book are killed, soils and the environment is demolished? How to convince the youth of rich countries to protect the environment when their states assist in environmental terrorism for motives of gain? It is obvious that the indisputable condition for the effectiveness of education in the field of sustainable development is the economic factor. Poverty and the pursuit of gain are the obstacles that are the most difficult to overcome on the way to eco-development.

\section{Morality as a condition for the safe development of the humanity}

Consciousness is a way of attitude to the world intrinsic to a human through a socially developed system of knowledge fixed in the language. Consciousness is inseparably connected with thinking, and its basis is 
perceptional and substantial activities - practice. Being social in its origin and essence, consciousness arises only as individual consciousness of independent individuals.

A conscious person is characterized by the ability correctly to understand and evaluate the surrounding reality. The quality of this process depends on the level of the intelligence (consciousness).

Social being and social consciousness are the main interacting spheres (material and spiritual) of the life of each society. The main determining component of social being is the social production of material goods, what includes production resources and production relations. Social consciousness is economic, social, political, legal, moral, artistic, religious, philosophical, scientific, organizational and other views, as well as conceptions, ideas and theories. The authors adhere to an opinion about the primary nature of social being and the secondary nature of social consciousness, that is, to the theory that being determines consciousness.

Morality is one of the forms of social consciousness; it is a system of views, ideas, norms and assessments that regulate behavior of humans. Morality also performs cognitive, evaluative and educational functions. The components of morality are: moral activity (actions, behavior of people), moral relations, and moral consciousness. Morality is a historical category determined by the prevailing socio-political relations, socio-economic formation.

Morality is under the active influence of other phenomena of social and natural being, which are called in the scientific literature the guiding parameters of the morality system (social and natural factors), for example, the economic sphere of social life, religion, and special features of people who are the bearers of the morality.

The influence of these factors on morality assists in the development of its structure. This process is called self-organization of the morality. The imposition of morality is not very effective. Society rejects any imposed morality and is guided by the rules formed by the process of self-organization. The ways of development cannot be imposed on complexly organized socio-natural systems. Rather, we shall understand how to promote the own tendencies and how to bring systems to these 
paths $^{25}$. So the influence on the morality system is productive only if such influence is consistent with its own laws.

The morality of a society is corresponding to the governing parameters and other factors that influence it, and therefore it is not always the most perfect.

The formation of youth morality is the most important task of educational institutions.

The German philosopher and teacher J. Herbart, developing the theory of pedagogy, brought moral education to the fore: "The only task of education can be fully expressed just with one word: morality" 26 .

The role of moral education in the development of an individual is quite fully and vividly characterized by K.D. Ushinsky: "moral influence is the main task of education, that is much more important than the development of the mind on the whole and filling the head with knowledge" 27 .

In ethics, morality is generally understood as a system of norms, rules, requirements developed in the society and imposed on an individual in various spheres of its life and activities. Morality of a human is interpreted as the totality of its consciousness, skills and habits what is connected with the observation of these norms and rules and with meeting of these requirements.

The content of educational work on the moral formation of the applicant for education includes the formation of many moral relations, among which the following take a significant place: attitude towards the Motherland and other countries and nations; attitude towards people; attitude to labour; attitude towards him- or herself; attitude to the public domain and wealth, in particular thrift and environmental protection.

The fundamental nature of moral education is the development of such views and beliefs, in the presence of which a person behaves

25 Князева Е.Н., Курдюмов С.П. Основания синиргетики. Режимы с обострением, самоорганизация, темпомиры. Санкт-Петербург : Алетейя, 2002. C. 166.

26 Гербарт И.Ф. Избранные педагогические сочинения. Москва : Просвещение, 1940. Т. 1. С. 133.

27 Ушинский К.Д. Собрание сочинений : в 11 т. Т. 2 : Педагогические статьи, 1857-1861 гг. / редкол.: А.М. Еголин (гл. ред.), Е.Н. Медынский, В.Я. Струминский ; сост. и подгот. к печати В.Я. Струминский ; АПН РСФСР. Москва ; Ленинград : изд-во АПН РСФСР, 1948. С. 431. URL: http://elib.gnpbu.ru/text/ushinskiy_sobranie-sochineniy_t2_1948/go,2;fs,1. 
correctly due to its internal necessity, when its own views and beliefs serve as control.

Moral relations are associated with human activities and depend on it. Activity is a way of human being in the world, its ability to make changes in the reality. The development and improvement of the moral qualities of young people is impossible without the formation in them of a corresponding need and motivational sphere. In a society with a low level of morality and a double essence, this is quite difficult to do.

In the preservation and acquisition of spirituality by a person, liberal arts education plays an important role. "The general essence of liberal arts education is that a person turns into a spiritual being" 23 .

According to H.G. Gadamer ${ }^{28}$ education, as a real reorganization of a person's inner world, forms the "openness of an individual to the surrounding reality".

The quality of liberal arts education does not always meet the requirements of the present. The reason for this state, according to the authors, may be the disadvantages of the educational system.

The credit-transfer system of education organization has advantages associated with the organization of education, but not in assisting in the growth of its quality. The introduction of basic and selective disciplines into the educational process can have a bad effect on the level of qualifications of future specialists and their understanding of their role in their lives and the society as a whole. The Humanities have a fairly small percentage in the curriculum today; most of them are classified as selective disciplines. And since the spiritual and cultural development of a person is based on the humanitarian component, the above-mentioned innovations have a negative effect on the effectiveness of the educational system of educational institutions.

Consumer goals of the existence have overshadowed people's vision of the system of modern civilization and its attitude both to people and to the environment that is surrounding them.

A characteristic feature of the educational system today is its radical simplification, specialization and unification. Such measures will lead to the destruction of the spiritual foundations of the national world view.

28 Ушинский К.Д. Собрание сочинений : в 11 т. Т. 3 : Педагогические статьи, 1862-1870 гг. / редкол.: А.М. Еголин (гл. ред.), Е.Н. Медынский, В.Я. Струминский ; сост. и подгот. к печати В.Я. Струминский ; АПН РСФСР. Москва ; Ленинград : изд-во АПН РСФСР, 1948. 655 с. URL: http://elib.gnpbu.ru/text/ushinskiy_sobranie-sochineniy_t3_1948/fs,1. 
The thoughtless adoption of foreign experience has negative effects on the quality of the attitude development and education. This is due to the difference in the mentality of different nations. "The educational ideas of each nation are permeated to such an extent that it is impossible even to think to transfer them to a foreign ground <...> since only their dead form is transferred, but not the life-giving essence" ${ }^{\text {29 }}$.

Another disadvantage of modern education is its narrow professional orientation, what prevents ensuring of the consistency of the entire set of general academic subjects, has a negative effect on the quality of skills and knowledge and integration of an individual, and therefore causes dissatisfaction with education and amorality.

\section{CONCLUSIONS}

The analysis of the current condition of the education for sustainable development in the world, studies of the experience of states in the formation of an effective and targeted national policy for the implementation of sustainable development goals and, in particular, solving of the educational problems allow to draw some of the most important conclusions and make some proposals.

1) At the current stage of development of human civilization, the pressing on the environment is approaching a critical point. Therefore, the search for ways for restoration of the harmony in the triad "human nature - universe" is one of the most pressing problems of the present. The studies show that since the 1970s, when the Concept of Sustainable Development started taking shape up to the present days, significant progress has been made in familiarization of the world's population with its content, but there are still very few practical changes for the better in implementation within the boundaries of the world.

2) Safety is the basis for sustainable development of each society. Issues on protection against risks are of top priority. The effectiveness of avoiding the threats depends on how much their causes are specified and explained. A detailed study of the problem associated with the risks gives ground to assert that the cause of most of them is a human factor. Involvement of human in the generation of threats gives grounds for

29 Ушинский К.Д. Собрание сочинений : в 11 т. Т. 3 : Педагогические статьи, 1862-1870 гг. / редкол.: А.М. Еголин (гл. ред.), Е.Н. Медынский, В.Я. Струминский ; сост. и подгот. к печати В.Я. Струминский ; АПН РСФСР. Москва ; Ленинград : изд-во АПН РСФСР, 1948. С. 195. URL: http://elib.gnpbu.ru/text/ushinskiy_sobranie-sochineniy_t3_1948/fs, 1 . 
activation of the issues on safety and risks in educational institutions and increase of their importance in the educational process.

3) The main goal of education for sustainable development is to develop in people and society the qualities that shall be able to ensure the effectiveness of eco-development. The studies carried out by the authors have shown that there are many obstacles on the way of achievement of the formulated goals. One of them is the low level of knowledge of applicants for education. The cause, according to the authors, may be transfer of the experience of other countries into the system of national education without taking into account the national traditions and conditions. Considering that the level of quality of education in a state correlates with the level of its economic development, it is obvious that achievement of the sustainable development goals in less developed countries will be problematic. For quick achievement of the goals of sustainable development on a global scale, it makes sense for International institutions to develop mechanisms for activation of the economies of backward countries.

4) Within the scope of this work, the role of moral education in the development of an individual was substantiated, since morality assists in the humanization of relationships between people, avoidance of conflicts and a conscious attitude towards nature both in local and in global dimensions. Morality as one of the forms of social consciousness is a strong force in uniting of the world community and its gradual transformation into a community of concerted actions, and it is also a condition for ensuring of the consistency in the development of the biosphere and human society, what is called coevolution.

\section{SUMMARY}

The work focuses on problematic issues related to education for sustainable development (ESD). The authors set forth their vision of their solution. By use of well-known methodologies, including a synergistic one, the main components of the ESD are identified (safety, knowledge, morality). Taking into account the interdependence between the level of education quality and the level of economic development of the state, the authors focus on the problematic character in relation of achievement of sustainable development goals in less developed countries. The work focuses on the interdependence between dangers and risks and the human factor, as well as on the role of morality in creation of a world community of concerted action. The expediency is shown: in the field of education, when adopting the experience of other countries, the national 
traditions and conditions shall be taken into account; in the educational process, the importance of the issues on safety and risks shall be increased; the influence on the youth moral system as a factor for avoidance of conflicts and a conscious attitude to the nature shall be increased. The practical importance of the study lies in the fact that it makes possible to determine the most effective directions for solution of the educational problems that have relation to sustainable development.

\section{References}

1. Education for Sustainable Development Goals: Learning Objective / UNESKO Education Sector. 2017. 67 p. URL: https://www.unesco.de/sites/default/files/2018-

08/unesco_education_for_sustainable_development_goals.pdf (дата звернення: 21.04.2021).

2. Организация Объединенных наций / Экономический и Социальный Совет. Европейская экономическая комиссия. Стратегия ЕЭК ООН для образования в интересах устойчивого развития. Материалы Совещания высокого уровня представителей министерств окружающей среды и образования (Вильнюс, 1718 марта 2005 года). Вильнюс, 2005. URL: https://unece.org/DAM/ env/documents/2005/cep/ac.13/cep.ac.13.2005.3.rev.1.r.pdf (дата звернення: 21.04.2021).

3. Цілі сталого розвитку: Україна : національна доповідь / Міністерство економічного розвитку і торгівлі України, 2017. 176 с. URL: http://un.org.ua/images/SDGs_NationalReportUA_Web_1.pdf.

4. Висоцька О.Є. Освіта для сталого розвитку : науковометодичний посібник. Дніпропетровськ : Роял Принт, 2011. 200 с.

5. Хмелевська О.М. Освіта для сталого розвитку: зміст та інституції. Демографія та соиіальна економіка. 2018. № 1 (32). C. 29-42.

6. Jeffrey D. Sachs. The Age of Sustainable Development. New York, US : Columbia University Press, 2015. 543 p. URL: file:///C:/Users/User/Downloads/Sachs.\%20\%20Food\%20Security.pdf.

7. Wolff L-A, Sjöblom P., Hofman-Bergholm M., Palmberg I. High Performance Education Fails in Sustainability? - A Reflection on Finnish Primary Teacher Education. Education Sciences. 2017. № 7 (1). P. 32. URL: https://doi.org/10.3390/educsci7010032.

8. Кочеткова Т.Ю. Парадигма самоорганизации и современная экологическая ситуация. Практическая философия. 2003. № 1. C. 105-113. 
9. Украинский Советский Энциклопедический Словарь : в 3 т. / редкол.: А.В. Кудрицкий (отв. ред) и др. Киев : Глав. Ред УСЭ, 1989. Т. $3.772 \mathrm{c.}$

10.Васильєва О.М., Фугело М.А., Фугело П.М. Формування культури як основа гуманізації буття. Освітній дискурс : збірник наукових праць. Вип. 23 (5). Київ : Науково-інформаційне агентство «Наука, технологія, інформація», 2020. С. 39-54. DOI: 10.33930/ed.2019.5007.23(5)-4.

11.Шпенглер О. Закат Европы. Очерки морфологии мировой истории. Москва : Мысль, 1993. 584 с.

12.Вебер А.Б. Глобальное изменение климата. Кто виноват? И что делать? Век глобализаџии. 2008. № 1. С. 70-75.

13.Данилов-Данильян В.И., Лосев К.С. Потребление воды: экологический, экономический, социальный и политический аспекты. Москва : Наука, 2006. 221 с. URL: http://ecsocman.hse.ru/text/33440596.

14.Ваганов П.А., Манг-Сунг Им. Экологические риски. СанктПетербург : изд-во Санкт-Петербургского университета, 2001. 152 с.

15.Винниченко В.К. Конкордизм. Система будування щастя: етико-філософський трактат / передмов. Т.І. Гундорової. Київ : Український письменник, 2011.335 с.

16.Програма XXI : Конференція ООН 3 навколишнього середовища та розвитку, червень 1992 р. Ріо-де-Жанейро, 1992. URL: https://www.un.org/ru/documents/decl_conv/declarations/ riodecl.shtml.

17.Сучасний тлумачний словник української мови: 60000 слів / за заг. ред. В.В. Дубічинського. Харків : ВД «ШКОЛА», 2009. 832 с.

18.Ярочкин В.И. Секьюритология - наука о безопасности жизнедеятельности. Москва : Ось-89, 2000. 400 с.

19.Економічна енциклопедія : у 3 т. Т. 3 / С.В. Мочерний (відп. ред.) та ін. Київ : вид. центр «Академія», 2002. 952 с.

20.Бек У. От индустриального общества к обществу риска. THESIS. 1994. № 5. C. 161-168.

21. Луман Н. Понятие риска. THESIS. 1994. № 5. С. 135-160.

22.Ортвин Р. Три десятилетия исследования риска: достижения и новые горизонты. Вопросы анализа риска. 1999. T. 1. № 1. С. 80-90.

23.Князева Е.Н., Курдюмов С.П. Основания синиргетики. Режимы с обострением, самоорганизация, темпомиры. Санкт-Петербург : Алетейя, 2002. 144 с. 
24.Гербарт И.Ф. Избранные педагогические сочинения. Москва : Просвещение, 1940. Т. 1. 294 с.

25. Ушинский К.Д. Собрание сочинений : в 11 т. Т. 2 : Педагогические статьи, 1857-1861 гг. / редкол.: А.М. Еголин (гл. ред.), Е.Н. Медынский, В.Я. Струминский ; сост. и подгот. к печати В.Я. Струминский ; АПН РСФСР. Москва ; Ленинград : издво АПН РСФСР, 1948. 655 c. URL: http://elib.gnpbu.ru/text/ushinskiy_ sobranie-sochineniy_t2_1948/go,2;fs, 1 .

26.Гадамер Х.-Г. Истина и метод: Основы философской герменевтики / пер. с нем. ; общ. ред. и вступ. ст. Б.Н. Бессонова. Москва : Прогресс, 1988. 704 c. URL: http://yanko.lib.ru/books/ philosoph/gadamer-istina_i_metod.pdf.

27. Ушинский К.Д. Собрание сочинений : в 11 т. Т. 3 : Педагогические статьи, 1862-1870 гг. / редкол.: А.М. Еголин (гл. ред.), Е.Н. Медынский, В.Я. Струминский ; сост. и подгот. к печати В.Я. Струминский ; АПН РСФСР. Москва ; Ленинград : изд-во АПН PCФСР, 1948. 655 c. URL: http://elib.gnpbu.ru/text/ushinskiy_sobraniesochineniy_t3_1948/fs, 1 .

\section{Information about the authors:} Vasylieva O. M., orcid.org/0000-0002-0608-5709

Candidate of Psychological Sciences, Associate Professor, Associate Professor at the Department for Vocational Training State Agrarian and Engineering University in Podilya 13, Shevcheko str., Kamianets-Podilskyi, Khmelnytsk region, 32300, Ukraine

Fugelo P. M., orcid.org/0000-0002-2166-0206 Candidate of Economic Sciences, Associate Professor, Associate Professor at the Department of Finance, Banking and Insurance State Agrarian and Engineering University in Podilya 13, Shevcheko str., Kamianets-Podilskyi, Khmelnytsk region, 32300, Ukraine 